The Historical fournal, 46, 3 (2003), pp. 669-701 (C) 2003 Cambridge University Press DOI: Io.IoI7/Soor8246Xo3oo3200 Printed in the United Kingdom

\title{
THE RESPONSE OF THE MODERATE WING OF THE CIVIL RIGHTS MOVEMENT TO THE WAR IN VIETNAM*
}

\author{
S I MON H A L L \\ University of Leeds
}

\begin{abstract}
This article explores the response of the moderate wing of the civil rights movement to the war in Vietnam. The moderates, made up of the National Association for the Advancement of Colored People (NAACP), the National Urban League, and leaders such as Bayard Rustin and A. Philip Randolph, were initially opposed to the civil rights movement taking a stand against the war. This reluctance was the result of a number of factors, including anti-communism and their own closeness with the administration of President Lyndon Fohnson. Crucially, it also resulted from their own experiences of the black freedom struggle itself. The article also documents and analyses the growing anti-war dissent amongst the moderates, culminating in the decision of both the NAACP and the Urban League to adopt an anti-war stance at the end of the Ig6os. Despite this, they remained unenthusiastic about participating in peace movement activities, and the reasons for this are explained. Finally, the article suggests that the war was important in exposing existing divisions within the civil rights movement, as well as in generating new ones.
\end{abstract}

I

On 4 April I967, Martin Luther King, Jr, launched a powerful attack on America's war in Vietnam. Speaking from the pulpit of New York City's Riverside Church, the nation's most prominent civil rights leader condemned the war for undermining the Great Society and for disproportionately taking African Americans to die abroad for freedoms they did not yet enjoy at home. Portraying the conflict as a civil war in which America had needlessly meddled, King charged his own government with being the 'greatest purveyor of violence in the world today'. 1 The Riverside speech was one of the strongest attacks on the Vietnam War by a prominent African American, but King was far from the only black leader to oppose it. In January I966, the Student Nonviolent Coordinating

* I would like to thank Tony Badger, John Thompson, Adam Fairclough, and the anonymous reviewers for the Historical foumal for their helpful comments on earlier drafts of this article. Financial help from the British Academy and the Lyndon Baines Johnson Foundation is also gratefully acknowledged.

1 Peter J. Ling, Martin Luther King, fr. (London and New York, 2002), pp. 265-7. 
Committee (SNCG) formally opposed the war, and they were soon followed by the Congress of Racial Equality (CORE); Muhammad Ali and the Black Panthers also bitterly denounced it. Nevertheless, the civil rights movement was far from united in its reaction to Vietnam, and a number of important organizations and influential individuals were extremely reluctant to take a position on the conflict.

This article seeks to explore the reaction to the Vietnam War of the moderate wing of the civil rights movement. Unlike the militants of SNCC and CORE, the Black Panther revolutionaries, or the increasingly radical King, the moderate wing of the movement, which had always been somewhat ambivalent about direct action and street protest, continued to believe in working within the American political system to bring about change. It also retained its faith in the ability of the federal government to solve the race problem through legislation and anti-poverty programmes. The moderate wing was made up of numerous groups and leaders, but at its centre stood the National Association for the Advancement of Colored People (NAACP). America's largest and oldest civil rights organization had grown increasingly conservative in the years following the Second World War. During the I940s and I95os the Association had attempted to dissociate itself from more radical civil rights groups such as CORE, and it had accepted the domestic and foreign implications of anti-communism. Although the NAACP supported many of the civil rights demonstrations of the rg6os, frequently supplying bail money and legal help, it remained lukewarm to the tactics of protest. Robert Cook, for example, has argued that the Association 'failed to embrace wholeheartedly the concept of nonviolent direct action'. ${ }^{2}$ The organization preferred to concentrate its efforts in Washington, DC, in an attempt to win support for progressive legislation by lobbying congressmen, and by using litigation to strike down segregation laws. ${ }^{3}$ The NAACP's executive director, Roy Wilkins, was a prominent civil rights moderate. After an early career in journalism, Wilkins had been appointed assistant secretary of the NAACP in 1931. Three years later he replaced W. E. B. Du Bois as editor of the Crisis, the Association's magazine, before succeeding Walter White as head of the organization in 1955. According to Robert Cook, Wilkins was 'temperamentally unprepared' to commit the Association to a strategy of civil disobedience and protest. He was also equivocal about the efforts of groups like SNCC to build a civil rights movement from the bottom up by fostering indigenous black leadership and empowering local African Americans. ${ }^{4}$

${ }^{2}$ Robert Cook, Sweet land of liberty? The African-American struggle for civil rights in the twentieth century (London and New York, I998), p. I 8.

${ }^{3}$ Denton L. Watson, 'Reassessing the role of the NAACP in the civil rights movement', Historian, 55 (I993), pp. 453-68; and Watson, 'The papers of the "Iorst senator": Clarence Mitchell Jr. and civil rights', Historian, 63 (2002), pp. 623-41.

${ }^{4}$ Roy Wilkins with Tom Matthews, Standing fast: the autobiography of Roy Wilkins (New York, I994), pp. xi, I9, 45-6, 48-9, 55-6, I04-7, I54-5, 220; see, for example, John Dittmer's account of how the National Association for the Advancement of Colored People (NAACP) national leadership helped to 
The moderate wing also included the National Urban League (NUL) and its leader, Whitney M. Young, Jr. Young, a native of Kentucky and former Dean of Social Work at Atlanta University, was appointed executive director of the Urban League in 1960. At six feet two inches tall and weighing around two hundred pounds, he cut an imposing figure. Young's biographer, Nancy J. Weiss, has written that 'everyone who knew him remarked on his style: frank, without pretense; exuberant, eager to take on the challenges and pleasures of life; aggressive, indefatigable, a study in perpetual motion'. Though traditionally a black social service agency rather than a protest organization, Young helped to make the Urban League a part of the civil rights movement. While he 'led no demonstrations and changed no laws', Young's work, out of the public eye, in selling civil rights to powerful whites and trying to secure greater job opportunities for black Americans was vitally important. He was also able to act as an effective mediator within the civil rights movement, helping to keep the peace and smooth over tensions. Bayard Rustin described him as an essential part of 'the concrete that kept the bricks from falling apart'. ${ }^{\mathbf{5}}$

Rustin himself is something of an enigmatic figure within the civil rights movement. Initially no moderate, the chain smoking, guitar playing, folk singing Quaker became less radical as the ig6os progressed. Rustin, a former field secretary with the pacifist Fellowship of Reconciliation (FOR), had helped tutor Martin Luther King in Gandhian nonviolence during the Montgomery Bus Boycott. He also played a critical role in the founding of the Southern Christian Leadership Conference (SCLC) in I957, and was largely responsible for organizing the August I963 March on Washington, at which Martin Luther King delivered his memorable 'I Have a Dream' speech. ${ }^{6}$ By the mid-ig6os, however, Rustin - along with his mentor A. Philip Randolph - was urging the civil rights movement to move from the streets into legislative halls and courtrooms. This contrasted with civil rights activists from the radical wing of the movement who were becoming increasingly critical of mainstream American institutions and values. $^{7}$

Between I965 and I968, the moderates refused to take a position on the war in Southeast Asia, believing that to do so would only harm the struggle for black equality. They adopted what Manfred Berg has termed the 'separate issues doctrine', which held that the war and civil rights were entirely distinct issues that

\footnotetext{
blunt the radicalism of the movement in Jackson, Mississippi - John Dittmer, Local people: the struggle for civil rights in Mississippi (Urbana and Chicago, I994), pp. I6o-9; Cook, Sweet land of liberty?, pp. II7-I8, 223. For the grass-roots perspective, see especially Charles M. Payne, I've got the light of freedom: the organizing tradition and the Mississippi freedom struggle (Berkeley, Los Angeles, and London, I995).

${ }^{5}$ Nancy J. Weiss, Whitney M. Young, Fr., and the struggle for civil rights (Princeton, NJ, I989), pp. xi-xii, 4, IIg.

6 Adam Fairclough, Better day coming: blacks and equality, I89o-200o (New York and London, 200I), p. 236; Ling, Martin Luther King, Fr., pp. 47-8; and Jervis Anderson, Bayard Rustin: troubles I've seen: a biography (Berkeley, Los Angeles, and London, I997), pp. I86-9, I98, 247-64.

7 Cook, Sweet land of liberty?, pp. 20I-2, 208.
} 
should not be mixed. ${ }^{8}$ For example, NAACP executive director Roy Wilkins insisted that diverting attention to Vietnam would weaken the fight for black progress, while Bayard Rustin argued that involvement of civil rights groups in anti-war activities would be 'distinctly unprofitable and perhaps even suicidal'. From 1969, the moderates finally spoke out against the war, but remained unenthusiastic about participating in anti-war activities.

A detailed analysis of the moderates' response helps us to expand our understanding of the civil rights movement. Indeed, while we know a good deal about those African American groups that opposed the war, those who did not take a stand have tended to be dismissed as conservative sell-outs. Many historians of the civil rights movement appear to have shared, at least implicitly, the view of one contemporary critic who believed that the NAACP had become 'little more than an Administration houseboy'. ${ }^{10}$ The time for a more nuanced explanation is long overdue.

\section{I}

Roy Wilkins had, as early as July 1965 , stated his belief that if the civil rights movement went 'off on a foreign policy kick' it would 'weaken its effectiveness in discharging its major responsibility' at home; and he consistently resisted attempts to link the peace and freedom movements. ${ }^{11}$ In the summer of ${ }^{9} 965$, for example, Wilkins attacked the Assembly of Unrepresented People, an early attempt at bringing together the peace, civil rights, and anti-poverty causes. ${ }^{12}$ The NAACP head believed that white radicals were trying to manipulate blacks into supporting anti-war activities by feigning concern over civil rights. Wilkins warned local NAACP leaders against becoming involved in the AUP, told them that 'organized units' of the Association had no authority to participate, and, recognizing that it was 'difficult for the public to dissociate them from the

${ }^{8}$ See Manfred Berg, 'Guns, butter, and civil rights: the National Association for the Advancement of Colored People and the Vietnam War, I964-I968', in David K. Adams and Cornelius A. van Minnen, eds., Aspects of war in American history (Keele, I997), p. 220.

${ }^{9}$ Letter from Roy Wilkins to Joseph Stern, I7 Mar. I966, in NAACP papers, group IV box A86, folder 'Vietnam correspondence, I966', Library of Congress, Washington, DC; report from the New York Times, 3 Aug. I965, C.P. I6, in Howard Zinn papers (processed), box 3, folder 5, State Historical Society of Wisconsin (SHSW), and Bayard Rustin, 'Dr. King's painful dilemma', in Bayard Rustin, Down the line: the collected writings of Bayard Rustin (Chiacgo, I97I), pp. I69-70.

${ }^{10}$ Henry Wallace to John Morsell, I3 Jan. I966, in NAACP papers, group IV box A86, folder 'Vietnam correspondence, I966', Library of Congress. Although Manfred Berg's analysis of the NAACP is quite sympathetic, he still accuses the organization of 'moral and intellectual hypocrisy' in not opposing the war. See Berg, 'Guns, butter, and civil rights', p. 2 I4.

11 'Sidetrack', New York Post, I8 July i965, Roy Wilkins papers, box 39, folder 'Newspaper column clippings, I964-I965', Library of Congress.

12 Charles DeBenedetti, An American ordeal: the antiwar movement of the Vietnam era, assisting author Charles Chatfield (Syracuse, I990), p. I20; and 'We declare peace: call for an assembly of unrepresented people in Washington, D.C., on August 6 through 9', p. I, papers of the Congress of Racial Equality, I944-68 (microfilm), reel 9, f 42, SHSW. 
organization', requested that they heed his advice. ${ }^{13}$ When SNCC opposed the war in January I966, Wilkins made his disdain clear in his national newspaper column. He pointed out that SNCG, which was a tiny group within the civil rights movement and was fast losing influence, had adopted the official leftist line on Vietnam. Wilkins reassured his readers that the bulk of the movement did not agree with SNCC's militant statement. ${ }^{14}$ Indeed, Wilkins's position on Vietnam was shared by the rest of the moderate black movement, including Whitney Young, A. Philip Randolph, and Bayard Rustin.

Martin Luther King's blistering attack on the Vietnam War elicited a strong response from the NAACP. On Io April I967, the organization's national board of directors passed a unanimous resolution declaring that any attempt to merge the peace and civil rights movement was 'a serious tactical mistake' and pledging that the NAACP would 'stick to the job for which it was organised'. ${ }^{15}$ Although King was not mentioned by name, there was no doubting that he was the intended target of the attack. ${ }^{\mathbf{1 6}}$ A few days later, Wilkins wrote that although King had the right to express his views on the war, he did not speak for the whole civil rights movement. ${ }^{17}$ Then, in August I967, Wilkins accused those black leaders who were 'moaning about' the war of neglecting the fight for civil rights at home and giving too much attention to 'Asia, Africa, and the islands of the sea' ${ }^{18}$ While some NAACP members resented such attacks on King, only a handful protested or resigned - though it is likely that a much larger number kept their grumblings to themselves. ${ }^{19}$

Vietnam's potential to break apart the NAACP was one reason why the Association was so reluctant to take a position on the conflict, at least so long as the majority of Americans supported the war. In January ig66, NAACP assistant executive director John Morsell explained that his organization's membership comprised a 'wide range of party loyalties and ... opinions on a variety of issues', there was unanimity only on the concern for racial justice. ${ }^{20}$ A couple of months later Roy Wilkins asserted that the NAACP had no right to assume that

${ }^{13}$ Report of the executive director for June, July, and August, 1965, I3 Sept. 1965, Papers of the NAACP: supplement to part $I, I 96 I-I 965$, editorial advisor August Meier, ed. Mark Fox (Frederick, MD, I982-97), reel I, Cambridge University, England; and memo from Wilkins to branch and youth council presidents re 'Washington, D.C. Jamboree August 6-9, I965', 3o July I965, NAACP papers, group III box A328, folder 'Vietnam War, I964-1965', Library of Congress.

14 Roy Wilkins, 'SNCC's foreign policy', I6 Jan. I966, in Roy Wilkins papers, box 39, folder 'Newspaper column clippings, I966', Library of Congress.

15 David J. Garrow, Bearing the cross: Martin Luther King, Fr., and the Southern Christian Leadership Conference (London, I993), p. 555; and Berg, 'Guns, butter, and civil rights', p. 223.

16 Garrow, Bearing the cross, p. 555.

17 'Dr. King's new role', New York Post, I5 Apr. I967, Roy Wilkins papers, box 39, folder 'Newspaper column clippings I967-I969', Library of Congress.

18 Roy Wilkins, 'LBJ's programs would aid negro', Detroit News, 26 Aug. 1967, office files of Frederick Panzer, box 33I, folder - civil rights i967-8, Lyndon Baines Johnson Presidential Library, Austin, Texas (LBJ). $\quad{ }^{19}$ Berg, 'Guns, butter, and civil rights', p. 224.

${ }^{20}$ Letter from John Morsell to Henry Wallace, Io Jan. I966, in NAACP papers, group IV box A86, folder 'Vietnam correspondence, I966', Library of Congress. 
members who had signed up for the civil rights fight would 'want their civil rights organization to commit them to a stand on the Vietnamese War'. ${ }^{21}$

Certainly, moderate civil rights leaders feared that adopting an anti-war position would both harm their own organizations and weaken support amongst mainstream America for the black movement. However, the decision to take no position on the war was the result of a number of factors. Manfred Berg has argued that the NAACP's reaction to the war was moulded by concepts of loyalty and patriotism that had formed an essential part of the civil rights struggle for decades, and rested upon the notion that a moderate, integrationist civil rights organization could not afford to oppose a war that was being fought in the name of democracy. ${ }^{22}$ Indeed, opposing the war threatened to alienate many patriotic African Americans, who understood that military service and loyalty had previously served as an effective tool for black advancement. However, this article seeks to give greater emphasis to two other factors that Berg has discussed in his work on the NAACP, though applying them to the moderates as a whole - the personal and political closeness of moderate civil rights leaders to the Johnson administration, and their anti-communism. More important, however, the response of the moderates will be placed within a context of organizing experience.

\section{I I}

The experiences of civil rights workers, who were active at the grass-roots level with groups like SNCC and CORE during the early ig6os, led to many of them becoming frustrated and disillusioned with the federal government, the Democratic Party, and white liberals. The national government's failure to protect civil rights activists from the violent assaults of segregationists was, perhaps, the most important factor in radicalizing much of the direct action wing of the black movement. In addition, the doomed attempt of the Mississippi Freedom Democratic Party (MFDP) to win recognition at the r964 Democratic National Convention convinced many in SNCG that white liberal allies could not be trusted, and that the Democratic Party was part of the problem, not part of the solution. In January 1967, for example, Stokely Carmichael told a crowd in Detroit that, while some called the Democratic Party the 'salvation of the Negro people', it was actually 'the most treacherous enemy the Negro people have. George and Lurleen Wallace run the Democratic Party in Alabama. As far as I'm concerned, they're bedfellows with ... former Attorney General [Nicholas] Katzenbach. ${ }^{23}$ Behind the hyperbole and rhetorical excess of the SNCC chairman lay genuine feelings of bitterness and disillusionment.

On the ground experience of grass-roots organizing frequently bred radicalism and fostered disillusionment with the federal government and white

\footnotetext{
${ }^{21}$ Letter from Roy Wilkins to Joseph Stern, I7 Mar. I966, in NAACP papers, group IV box A86, folder 'Vietnam correspondence, ig66', Library of Congress.

22 See Berg, 'Guns, butter, and civil rights', p. 2 I4.

23 'Carmichael assails Democrats, Liberals', Washington Post, I9 Jan. I967.
} 
liberals -thereby increasing the likelihood of cynicism about the war or outright opposition to it. Bob Moses, for example, believed that those who had been a part of the Southern civil rights movement were best equipped to understand the 'sick' way in which America viewed the rest of the world. ${ }^{24}$ When SNCC released its anti-war statement in January I966 it explained that 'our work, particularly in the South, taught us that the United Sates government has never guaranteed the freedom of oppressed citizens' ${ }^{25}$ In many ways, anti-war sentiment flowed from the organizing experience itself. As Howard Zinn explained in I965, opposition to the war among Southern black activists came 'from the cotton fields, the country roads, the jails of the Deep South, where these young people have spent much of their time'. ${ }^{26}$

However, the experience of civil rights moderates was markedly different. For them, the Democratic Party - at the national level - had been a staunch ally. It had passed the I964 and I965 civil rights acts, which destroyed the legal basis for Jim Crow segregation and promised an end to African American disfranchisement in the South. In addition, the Great Society offered the prospect of helping to end the biting poverty that afflicted a disproportionately high number of America's black citizens. Not only did such achievements confirm their belief in the innate goodness of America; it also convinced them that the future for progressive change lay in alliance with liberal Democrats. The moderates' position on Vietnam was, in many ways, a logical product of their previous experience within the civil rights movement.

Moreover, the NAACP's whole approach to solving the civil rights problem indeed its very analysis of the problem - differed markedly to that of the more radical groups. SNCC's philosophy of organizing, for instance, was based on participatory democracy, a faith in ordinary people; and it aimed at building local indigenous black insurgencies that would empower African Americans throughout the South. But the attitude of Roy Wilkins toward the locally orientated organizing strategy practised by SNCG was expressed clearly at the Atlantic City Convention. Although nominally a supporter of the MFDP, Wilkins's personal commitment to the cause is subject to some doubt. In a telephone conversation with Lyndon Johnson on I5 August i964, he explained that while he had to support the Freedom Party publicly, lest his position as a black leader become untenable, he would 'explore ways and means of blunting this thing' $\cdot{ }^{27}$ At Atlantic City Wilkins favoured the compromise of giving the MFDP two at-large seats and the promise of future reform, rather than recognizing them

24 '... One freedom worker's views', Southern Patriot, Oct. I965, p. 3.

25 Student Nonviolent Coordinating Committee (SNCG) statement on the war in Vietnam, 6 Jan. I966, in Massimo Teodori, The new left: a documentary history (London, I970), p. 25I.

${ }^{26}$ Howard Zinn, unpublished article, winter I965 $_{5}$, in Howard Zinn papers, box 3, folder 5, SHSW.

27 Telephone conversation between Roy Wilkins and Lyndon Johnson, I5 Aug. I964, 9:50 a.m., recordings of conversations and meetings, recordings of telephone conversations - White House series, tape wH6408.2I, \#4940 and \#494I, LBJ. 
as the official Mississippi delegation, believing that ensuring a Johnson victory over Barry Goldwater - and having Hubert Humphrey as vice-president - were issues that took precedence. Wilkins's opinions of the indigenous black leadership that SNCG had nurtured were somewhat unflattering. At the convention he told Fannie Lou Hamer that 'you people have put your point across. You don't know anything, you're ignorant, you don't know anything about politics. I been in the business over twenty years ... Now why don't you pack up and go home? ${ }^{28}$

The fundamental objective of the NAACP had always been the full participation of African Americans in all phases of American life. ${ }^{29}$ The leaders of the NAACP were determined that nothing would deflect them from this goal. Herbert Hill, a former labour secretary of the Association, who possessed what one journalist described as a 'deep, voice-of-doom delivery that can bounce off walls in a Senate committee hearing room or hold a private audience of one in shell-shocked thrall' ${ }^{30}$ recalled Roy Wilkins's philosophy:

Our mission ... our sacred mission ... is to deal with, is the struggle for the rights of Blacks. We must never compromise, we must be undeterred, we must never let anything get in our way. Wilkins used to say 'Steady as she goes.' Everything in the organization is integrity, the NAACP, its leadership and membership must not be deflected by any other considerations. That was Wilkins' genuine feeling. So let King do whatever he wants, [James] Farmer can go, it's OK, they're flashes in the pan. That's the way he felt. They're here today, gone tomorrow. We will be here this year, next year and a hundred years from now. As long as there's racism in America, there will be an NAACP. And these others can go off, but not the NAACP. We remain firm and, his favourite phrase, 'Steady as she goes' ${ }^{31}$

Clearly, opposing the Vietnam War would have made the ship very unsteady.

Unlike the militants of SNCG, the NAACP did not advocate a revolutionary overhaul of the American socio-economic and political system. The Brooklynborn Hill, a music buff who was stimulated by the 'dramatic struggles of labor and eventually Negro labor', was one of the national NAACP's most radical officials. During the I940s and I950s he had embarked on an uncompromising crusade against racism in the labour movement - Roy Wilkins recalled that Hill, who was Jewish, 'grabbed hold of Jim Crow in the AFL-CIO and squeezed so hard you could hear George Meany's splutters all the way to New York ${ }^{32}$ Hill explained that:

the leaders of the NAACP were, that's in the past, the period we're talking about, we're not radicals, we're not revolutionary. I think for the most part we accepted the assumptions about American society, with the reservation that we ought to get rid of racial

${ }^{28}$ Fannie Lou Hamer, 22 Nov. 1966, Ruleville, MS, interview by Howard Romaine quoted in Eric Burner, And gently he shall lead them: Robert Parris Moses and civil rights in Mississippi (New York and London, I994), p. I86.

29 Wilkins, Standing fast, p. 32 I.

${ }^{30}$ Joseph Wershba, 'Daily closeup: Herbert Hill, NAACP's labor secretary', New York Post, I4 Dec. I959, p. 49. $\quad{ }^{31}$ Author's interview with Herbert Hill, I6 May 2000.

${ }^{32}$ See Wershba, 'Daily closeup: Herbert Hill'; Paula F. Pfeffer, A. Philip Randolph, pioneer of the civil rights movement (Baton Rouge and London, I990), pp. 226-32; and Wilkins, Standing fast, p. 22 I. 
discrimination. But they were not revolutionaries, they were not ... radicals. They were radicals on the subject of race, they were revolutionaries on the subject of race, but they identified with this society. ${ }^{33}$

Now, for the first time in American history, the national government also seemed to be committed to the goal of eradicating racial discrimination and opening up opportunities for African Americans. Speaking in I969, Roy Wilkins summed up his view of Lyndon Johnson:

he committed the White House and the Administration to the involvement of government in getting rid of the inequalities between people solely on the basis of race. And he did this to a greater extent than any other President in our history ... when the chips were down he used the great powers of the presidency on the side of the people who were deprived. ${ }^{34}$

In his autobiography, the NAACP executive director articulated his positive experience of working closely with the Johnson government. Wilkins stated that he often came away from conversations with LBJ 'feeling that he was not only with us but often ahead of us'. ${ }^{35}$ Wilkins explained how, in August of ig65, he had met with the president and explained that only nine midshipmen at the US Naval Academy in Annapolis were blacks. Johnson promised to get the secretary of defence to investigate, and the problem was quickly rectified. Wilkins explained that 'it was as easy as that in those years to do business with LBJ' ${ }^{36}$ Wilkins may have found things less easy had he been asking for federal protection in Mississippi or adequate FBI investigations into racially motivated crimes. Nevertheless, for the national leadership of the NAACP and other civil rights moderates, the national Democratic Party was, overwhelmingly, viewed as friend, not foe. The civil rights achievements of the Kennedy and Johnson administrations during the first half of the ig6os represented the fulfilment of the NAACP's dream of achieving racial equality through legislation and government intervention there was little room for bitterness or disillusionment, and less motivation to view the war in Vietnam as anything other than a necessary defence of freedom in the face of communist aggression.

\section{I $\mathrm{V}$}

In February i965, Commentary magazine carried Bayard Rustin's 'From protest to politics: the future of the civil rights movement'. In it Rustin, one of the foremost strategists of the civil rights movement, outlined his hopes and tactical approach for the rest of the decade. ${ }^{37}$ Rustin claimed that the civil rights movement was evolving from a protest movement into a fully fledged social movement and that the future of the black freedom struggle lay in a re-alignment of the Democratic

${ }^{33}$ Author's interview with Herbert Hill, i6 May 2000.

34 Transcript, Roy Wilkins oral history interview I, 4 Jan. I969, by Thomas H. Baker, internet copy, LBJ, p. I4. ${ }_{37}^{35}$ Wilkins, Standing fast, p. 32 I. ${ }^{36}$ Ibid., p. 32 I.

37 Anderson, Bayard Rustin, p. 284 . 
Party. ${ }^{38}$ Believing that the Johnson administration was determined to fulfil the promise of the New Deal, Rustin argued that direct action be replaced with politics. He declared that:

the future of the Negro struggle depends on whether the contradictions of this society can be resolved by a coalition of progressive forces which becomes the effective political majority in the United States. I speak of the coalition which staged the March on Washington, passed the Civil Rights Act, and laid the basis for the Johnson landslide - Negroes, trade unionists, liberals, and religious groups. ${ }^{39}$

The idea that the civil rights movement should seek further gains in alliance with the progressive wing of the Democratic Party was shared by Roy Wilkins, A. Philip Randolph, and the National Urban League's Whitney Young. Believing that the war did not preclude domestic progress, they argued that it was possible to have both guns and butter. ${ }^{40}$ Such a strategy in fact made forthright criticism of the Vietnam War impossible. The moderates understood that breaking with, or merely offending, the president over Vietnam would have repercussions for the Great Society programmes. This was recognized by Whitney Young when he told Martin Luther King that 'Johnson needs a consensus ... If we are not with him on Vietnam, then he is not going to be with us on civil rights. ${ }^{, 41}$ Anti-war critics like Staughton Lynd believed that Rustin's strategy of working with the Democratic Party required the implicit acceptance of the government's war policy. ${ }^{42}$ Lynd, for example, infamously accused Rustin of advocating coalition with the marines. ${ }^{43}$

Rustin's attitude appears odd given his history as a pacifist and his early opposition to the war in Vietnam - he had, for example, given a speech at a 1965 anti-Vietnam rally at New York's Madison Square Garden, organized by the National Committee for a Sane Nuclear Policy (SANE). ${ }^{44}$ In part it reflected his belief in the coalition strategy, but it also derived from his uneasiness with the anti-war movement itself. Rustin viewed the anti-war movement as being more anti-American than anti-war, and he was especially concerned by its romanticization of the Viet Cong. Rustin explained his views in a I967 letter to the New York Times in which he stated that no 'effective' and 'enduring' peace movement could be built, or win influence with the American people, if it became publicly identified with groups that desired a victory for the Viet Cong. ${ }^{45}$

\footnotetext{
${ }^{38}$ Bayard Rustin, 'From protest to politics: the future of the civil rights movement', Commentary (Feb. I965), quoted in Rustin, Down the line, p. II5. $\quad{ }^{39}$ Ibid., p. II9.

40 Cook, Sweet land of liberty?, p. I8I ; and Berg, 'Guns, butter, and civil rights', p. 225.

${ }^{41}$ Weiss, Whitney M. Young, Fr., p. I58. $\quad{ }^{42}$ Anderson, Bayard Rustin, p. 296.

43 Staughton Lynd, 'Coalition politics or nonviolent revolution?', Liberation (June-July I965), p. I8.

44 Anderson, Bayard Rustin, pp. 29 ${ }^{\mathrm{I}-2 .}$

45 Ibid., pp. 293 and 298. Rustin's dedication to the realignment of the Democratic Party played a role in his somewhat conservative stance with regard to the peace movement. It is also widely rumoured that Rustin began to work for the CIA. John D'Emilio, however, has placed Rustin's criticisms of the peace movement, and his more general move away from the political left, within the context of his homosexuality. Indeed, he goes so far as to claim that Rustin's political odyssey is a 'tale of gay
} 
Asa Philip Randolph, the veteran civil rights leader and founder of the first all-black labour union - the Brotherhood of Sleeping Car Porters - agreed with Rustin's strategy of coalition politics; like Rustin, his own position on the war was ambiguous. Randolph, whose militant anti-communism was rooted in the ideological battles that took place within the Socialist Party shortly after the Bolshevik Revolution, was a pragmatic pacifist who had opposed the First World War and, through his March on Washington Movement, had threatened massive civil disobedience during the war against Nazism. ${ }^{46}$ He was an early critic of the Vietnam War - at a demonstration in New York City on i9 December i964, for example, he 'pilloried America's foreign policy'; he had signed the 'Declaration of Conscience' against the war in Vietnam; and at the December i965 AFL-CIO convention in San Francisco he warned that America's poor were bearing the burden of the war and that the conflict was being used as an excuse to stall on civil rights. ${ }^{47}$

Randolph had been prepared to rock the boat during the Second World War and, given his early opposition to Vietnam, he might have been expected to do the same in the late I96os. But instead he sided with the no position adherents, and adopted the same line as the NAACP. The veteran black leader agreed with Bayard Rustin that co-operation with white allies and the federal government was the 'only feasible way of delivering power to an essentially powerless people', and this commitment to the strategy of coalition politics would prevent him from becoming an outspoken critic of Vietnam. ${ }^{48}$ Randolph, described by Roy Wilkins as the 'spiritual and historical father' of the Vietnam-era draft resisters, downplayed his personal opposition to America's use of military force in Southeast Asia and argued that it was 'tactically unsound' for a 'civil rights leader or a leader of the peace movement to attempt to assume a position of leadership in both ... at the same time. ${ }^{49}$ Randolph also disagreed with attempts to involve the civil rights

oppression'. D'Emilio argues that being stigmatized as a 'sex pervert' had helped Rustin to lose any attachment to 'left-wing romanticism'. He was thus critical of the peace movement's tendency toward radical posturing and third world romanticism and 'grasped the bankruptcy of radical marginality in a way that few of his peers did'. Rustin's homosexuality also resulted in him lacking an institutional base - Martin Luther King, for example, decided against bringing Rustin on to the Southern Christian Leadership Conference (SCLC) staff because of concerns over his sexuality. This lack of organizational roots, according to D'Emilio, made Rustin vulnerable to overtures from conservative organizations. Rustin eventually agreed to head the A. Philip Randolph Institute which, being funded by the AFL-CIO, greatly restricted his room for dissent. However, whilst D'Emilio's thesis is intriguing, it does not deal with the fact that many heterosexual radicals have suffered similar political conversions. See John D'Emilio, 'Homophobia and the trajectory of postwar American radicalism: the career of Bayard Rustin', Radical History Review, 62 (I995).

46 See Pfeffer, A. Philip Randolph, pp. I7-18, 21 and 43.

47 See DeBenedetti, An American ordeal, pp. 85 and Ioo; and Philip S. Foner, American labor and the Indochina war: the growth of union opposition (New York, I97I), pp. 30-2.

48 Cook, Sweet land of liberty?, p. 205.

49 Pfeffer, A. Philip Randolph, p. I49; undated paper, the papers of A. Philip Randolph, ed. John H. Bracey, Jr, and August Meier (microfilm project of University Publications of America, I990), reel 32, speeches and writings file, box 4I, 'Research notes and related material, undated, I96pp.', Sterling Memorial Library, Yale University (SML). See also Pfeffer, A. Philip Randolph, p. 278. 
movement in anti-war actions. He explained this position in some detail in the fall of 1966 :

May I say that I have expressed my opinion to civil rights leaders to the effect that it would be unfair to the Negro masses for the civil rights leaders to abandon the MississippiAlabama front and leave it exposed to the racists of the George Wallace stripe, and turn the Negro's attention and plunge him into participation in demonstrations to end the war in Vietnam. Having long experience in the field of mass movements, I am aware that you cannot fight on two fronts at the same time without sacrificing one. ${ }^{50}$

Randolph wrote that, while he was personally committed to seeing the war end 'at the earliest possible moment', the leadership of the civil rights movement had 'no mandate from the Negro masses ... to carry on any broad, massive movement to end the war in Vietnam ${ }^{51}$ Like Rustin, Randolph was uneasy with the radical elements of the peace movement - he was, for example, 'unequivocally opposed to burning of draft cards and especially to ... burning the flag of our country' ${ }^{52}$

On occasion Randolph appears to have indicated a measure of support for the war. In the spring of 1965 he wired LBJ, expressing approval of the president's 7 April Johns Hopkins address at which, in addition to re-affirming America's commitment to an independent South Vietnam, he had also stated his willingness to participate in 'unconditional discussions' with any government to try and end the war, and had outlined an ambitious \$I billion development programme for the Mekong River Valley. Johnson expressed gratitude for this 'most welcome' support. ${ }^{53}$ However, Randolph continued to harbour private doubts. On May 20 Norman Thomas wrote, expressing his opposition to America's recent military interference in the Dominican Republic. He declared that he was 'thoroughly convinced that what the U.S. is doing in the Dominican Republic and, I may add, Vietnam is doing more for communism than communism could do for itself'. Randolph replied the next day with a telegram in which he stated 'I agree with you. ${ }^{54}$ But while Randolph wanted to 'see the United States stop the bombing ... and disengage its military forces from involvement in South East Asia at the earliest possible date', he did not support a unilateral withdrawal, nor did he 'place all the blame for the continuance of the war on the United States'. Indeed, Randolph evidently believed that President Johnson was attempting to secure a just peace in Vietnam. ${ }^{55}$

${ }^{50}$ Letter, A. Philip Randolph to Jerome Davis, I4 Sept. 1966, in papers of A. Philip Randolph, reel 2, general correspondence, box 2, 'A-Y, Ig66' (SML).

${ }^{51}$ Ibid.

${ }^{52}$ Undated paper, papers of A. Philip Randolph, reel 32 , speeches and writings file, box $4 \mathrm{I}$, 'Research notes and related material, undated, ig6pp.' (SML).

${ }^{53}$ Garrow, Bearing the cross, p. 553; Pfeffer, A. Philip Randolph, p. 278; and DeBenedetti, An American ordeal, pp. 108 and Iı. See letter from Lyndon Johnson to A. Philip Randolph, I5 Apr. 1965, in papers of A. Philip Randolph, reel 2, general correspondence, box 2, 'A-W, I965' (SML).

${ }^{54}$ Letter, Norman Thomas to A. Philip Randolph, 20 May 1965, and telegram, Randolph to Thomas, 21 May 1965, in papers of A. Philip Randolph, reel 2, general correspondence, box 2, 'A-W, I965' (SML). Randolph did not refer to Thomas's comments about Vietnam.

${ }_{55}$ Undated paper, papers of A. Philip Randolph, reel 32 , speeches and writings file, box $4 \mathrm{I}$, 'Research notes and related material, undated, I96pp.' (SML). 
By the decade's end, Randolph applied a selective reading of his own actions when he explained that:

I have always been opposed to wars in principle ... Vietnam ... represents ... no defense of our vital national interest. The moral commitment of the American government went beyond the reaches of liberal concern for our own problems, in the sense that it committed an enormous and costly amount of the nation's resources to Vietnam - in terms of both money and human life. This, as I see it, is a great moral loss and a weakening of the country's moral fiber. As for Dr. King's decision to oppose the war, I cannot say I regard it as any great moral contradiction. He was, after all, one of the moral leaders of the country. Opposing wars and fighting for civil rights have natural and complementary motivations. And long before Dr. King came along, the Messenger, which I edited in World War I, was fighting for civil rights and opposing the war at the same time. ${ }^{56}$

In fact, during the mid-rg6os, Randolph believed that opposing the war was not a vital concern to the black freedom struggle; he feared that the peace movement would divert energy from the civil rights movement; and he held that the freedom movement had much to lose and little to gain by breaking with the Johnson administration in order to criticize the war in Vietnam. ${ }^{57}$ One does, though, get a strong sense of the private horror with which Randolph, along with Wilkins and Rustin, must have viewed developments in Southeast Asia. Just at the moment when the forces of progressivism seemed poised to triumph, the war in Vietnam threatened everything. Randolph encapsulated the tragedy of Ig6os liberalism when he wrote that 'the Vietnam War ... has practically pushed the civil rights movement off the center of the stage of American history'. Whilst the 'white liberals and students' were 'still for civil rights', they were now 'asking for peace in Vietnam, not for civil rights in Alabama and Mississippi' ${ }^{58}$

The Urban League's stance on Vietnam in many ways mirrored that of the NAACP, Randolph, and Rustin - it insisted that foreign policy and civil rights issues remain disconnected. As early as August 1965, the League's Delegate Assembly had approved a resolution recommending that the organization stay out of the burgeoning Vietnam controversy. The resolution called on the NUL to 'not divide nor divert its energies and resources by seeking to merge domestic and international issues where armed conflict is involved'. ${ }^{59}$ The Urban League, which attempted to increase black economic opportunities by using the tactics of persuasion and negotiation in American boardrooms to sell civil rights to powerful whites, had a somewhat restrained and cautious agenda. The League had joined the civil rights movement thanks to the efforts of its executive director, Whitney M. Young, Jr, and, of the 'big five' organizations, it was the one least

\footnotetext{
${ }^{56}$ Jervis Anderson, A. Philip Randolph: a biographical portrait (New York, I972), p. 331 ; and Anderson, Bayard Rustin, p. 30 I.

57 Pfeffer, A. Philip Randolph, p. 278.

58 Undated paper, papers of A. Philip Randolph, reel 32, speeches and writings file, box 4I, 'Research notes and related material, undated, i96pp.' (SML).

${ }^{59}$ Report from the New York Times, 3 Aug. I965, C.P. I6, in Howard Zinn papers, I956-94 (processed), box 3 , folder 5, SHSW.
} 
influenced by grass-roots pressure and most easily controlled by its national leadership. Young himself travelled to Vietnam in July ig66 on an independent fact-finding mission financed by the League, where he investigated the welfare of black troops fighting there. The NUL leader expressed pride in efforts of the black soldiers, whom he claimed had high morale and he emphasized interracial co-operation within the US armed forces, although he also drew attention to the lack of African American officers. Still, Young was careful to explain that he was not making any judgement on the conflict itself. ${ }^{60}$ It was a point that he made again in August, speaking on Meet the Press, when he stated that 'the Urban League takes no position on Vietnam. We know this, that we had a race problem in this country before Vietnam; we will have a race problem after it is gone. ${ }^{\mathbf{6 1}}$ He insisted that the civil rights movement focus on 'rats tonight and jobs tomorrow' ${ }^{62}$ Indeed Whitney Young disagreed vehemently with Martin Luther King's opposition to the war, and the two famously traded personal insults in March $1967 .^{63}$

The coalition strategy was cemented by the close personal relationship that Roy Wilkins and Whitney Young enjoyed with Lyndon Johnson. James Farmer recalled that LBJ 'adored' Whitney Young, and he became, along with Wilkins, a major adviser on White House civil rights initiatives. ${ }^{64}$ Dennis C. Dickerson has claimed that Young had 'insider status' during the Johnson years, and that he was consulted extensively about the war on poverty and other Great Society programmes. ${ }^{\mathbf{6 5}}$ Whitney Young's role as the 'inside man' of the black revolution, a figure who 'served as a bridge and interpreter between black America and the businessmen, foundation executives, and public officials who comprised the white power structure', and his relationship with LBJ, helped to shape his response to the Vietnam War. ${ }^{66}$

As well as sharing a political philosophy with the liberal leadership of the Democratic Party during the early ig6os, Roy Wilkins also enjoyed an extraordinarily close relationship with the 36 th president of the United States. Interviewed in I969, Wilkins confessed that he had great affection and admiration for Johnson. ${ }^{67}$ In his autobiography, Wilkins recalled his reaction to Johnson's message to Congress in support of voting rights legislation in March I965 - 'I had waited all my life to hear a President of the United States talk that way. There was a great roar of applause. I looked to my left and I looked to my right and I saw

\footnotetext{
60 Dennis C. Dickerson, Militant mediator: Whitney M. Young, fr. (Lexington, KY, I998), pp. 27I-3.

61 Weiss, Whitney M. Young, Fr., p. I58.

64 Dickerson, Militant mediator, p. 247.

62 Ibid.

65 Ibid., p. 257.

${ }^{66}$ Weiss, Whitney M. Young, Fr., p. xi; and Dickerson, Militant mediator, p. 270.

67 Transcript, Roy Wilkins oral history interview I, 4 Jan. I969, by Thomas H. Baker, internet copy,
}

LBJ, p. I4. 
men and women with their eyes full of tears. And at that moment, I confess, I loved LBJ. ' ${ }^{68}$

Lyndon Johnson certainly appears to have valued Roy Wilkins's friendship, and he shamelessly flattered the civil rights leader, frequently buttering up Wilkins in the official correspondence between the two men. In February ig66 he wrote to Wilkins, stating that he had 'always been a man on whom I could depend, regardless of the winds of change'. ${ }^{69}$ In September ig68 the president, whose capacity to flatter knew no bounds, told the NAACP head that he could call him any time he needed to - 'I am always proud and grateful to have you by my side. ${ }^{70}$ In the final days of his presidency, Johnson wrote to Wilkins, once again conveying great affection - '[your name] will live ... in my memory, where I will be grateful forever for the wise counsel, the unfailing generosity, and the selfless friendship you gave me throughout my Presidency. I hope we see each other often in the years ahead, Roy. God bless you. ${ }^{71}$

To a certain degree, the federal government appears actively to have courted the civil rights movement's more moderate leaders after i965. Indeed, a memorandum from George Reedy, LBJs press secretary, to the president in the autumn of ig65 declared that moderate civil rights leaders would be the most effective at consolidating the civil rights gains already made, and suggested that:

the Federal Government would be well advised to make a public point of consulting Randolph, Wilkins, and Young (particularly Wilkins) in the period immediately ahead. Frequent invitations to the White House would be in order and anything that could be done to increase his prestige would help to shift the focus from demonstrations in the streets to the type of constructive work that now is so badly needed. ${ }^{72}$

The federal government certainly cultivated Wilkins's support, but there can be little doubt that Wilkins and Johnson, besides sharing many of the same political goals, also developed a very close personal relationship. The NAACP executive director constantly received phone calls from Johnson, and Wilkins and his wife were regular guests for barbecue at Johnson's Texas ranch. ${ }^{73}$ NAACP labour secretary Herbert Hill recalled 'I don't think in the entire history of the NAACP the President of the United States had evolved such a close personal relationship with the head of the [Association]. ${ }^{74}$ This clearly was yet another reason why the NAACP refused to take a stand against the Vietnam War, especially considering

68 Wilkins, Standing fast, p. 307.

69 White House central file (WHCF) name file - Roy Wilkins, 24 Feb. I966, LBJ to Wilkins, LBJ.

70 WHCF name file - Roy Wilkins, 5 Sept. I968, LBJ to Wilkins, LBJ.

71 WHCF name file - Roy Wilkins, I7 Jan. I969, LBJ to Wilkins, LBJ.

72 Office files of Lee C. White, box 4, folder - civil rights - list of organizations and political leaders, memo from George Reedy to LBJ, 7 Sept. I965, LBJ.

73 Author's interview with Herbert Hill, I6 May 2000, and 9 Aug. 2000.

74 Author's interview with Herbert Hill, I6 May 2000. 
the very personal attacks that many anti-war movement participants made on the president. $^{75}$

The combination of the coalition strategy and personal affection for LBJ made criticism of the war in Vietnam a virtual impossibility. The only way in which the moderate wing of the civil rights movement officially interacted with the war was in using the conflict to advance the Great Society. For example, early in 1967 Whitney Young claimed that white liberals were using Vietnam as an excuse for their failure to support civil rights. In reference to northern housing drives he stated that 'when we began to talk about issues that involved them next door in their communities they suddenly decided there was a more important issue' Vietnam. Young concluded 'we are insisting that this country fight a war on poverty, and had better fight a war on poverty, with the same tenacity as in Vietnam ${ }^{76}$ At the end of June ${ }^{1967}$, shortly after the House of Representatives had voted by 232 to I7I to reject a \$IO million appropriation to extend a rent supplement programme, Whitney Young commented that: 'It is tragic that when the front pages are filled with pictures and stories of the courage of Negro soldiers dying in Viet Nam in disproportionate numbers that the Congress should see fit to reward their impoverished loved ones back home in the ghetto by cruelly cutting out any additional funds for rent supplements. ${ }^{, 77}$ Using the Vietnam War for the purpose of advancing a progressive domestic agenda had been adopted as official policy by the Council of United Civil Rights Leadership (a co-ordinating body set up in 1963 to raise money and encourage co-operation among civil rights groups) in March $1966 .{ }^{78}$ Believing that the Republic could afford both guns and butter, moderate civil rights leaders sought to apply pressure on an often recalcitrant Congress by using African American service in a foreign war as a bargaining chip. This was in the tradition of the Double $V$ strategy that had been employed so successfully during the Second World War, and it reflected the traditional way in which black America had attempted to use service for one's country as leverage. The flaw in the strategy by the late ig6os, however, was that there was virtually no leverage left - legal equality had recently been assured; the Great Society was already under serious political assault; and the forces of conservatism were preparing to reap the harvest of the white backlash. Some civil

75 The anti-war chant 'Hey, hey LBJ, how many kids did you kill today', is well known. One of the most notorious anti-war attacks on the president came from SNCC's Julius Lester who, in an article for the SNCG newsletter - later reprinted in the February I968 edition of the New South Student-advocated militant resistance to the war - 'To resist is to make the President afraid to leave the White House because he will be spat upon wherever he goes to tell his lies, because his limousine will find the streets filled with tacks and thousands of people who will surge around it, smashing the windows and rocking the car until it is turned on its side. Have we forgotten? The man is a murderer.' See Julius Lester, 'To hell with protest', New South Student, 5 (I968).

76 "Vietnam called "excuse" for lag in rights fight', Washington Post, 21 Jan. I967, in office files of Frederick Panzer, box 33I, folder - civil rights I967-8, LBJ.

77 National Urban League (NUL) newsletter - Washington Bureau, vol. I no. 4 (3o June 1967), p. 3.

78 Minutes, Council of United Civil Rights Leadership, 23 Mar. I966, NY. Copy in possession of author. 
rights leaders understood this, even as they held firm to the strategy. In February I968, Gloster Current, NAACP director of branches, explained that because of America's growing involvement in Vietnam, 'a wave of reaction has swept the land and it is not as easy to get progressive legislation passed. ${ }^{79}$

\section{I}

The close relationship between the moderate civil rights movement and the federal government was certainly a cause of concern among some of the rankand-file. One report of the I965 NAACP convention in Denver claimed that 'opposition that flared from the floor ... mirrored objections that the leadership was too closely tied with the Johnson Administration ". ${ }^{80}$ While the NAACP was able to contain dissent over Vietnam, it was forced to take a stronger position against the nomination of former Mississippi Governor James Coleman to a federal judgeship. ${ }^{81}$ The initial, mild resolution prompted claims from the floor that a deal had been struck with Johnson, and Wilkins was forced to deny that he had been offered a cabinet position. It was an incident that the NAACP's Herbert Hill remembered clearly some thirty-five years later:

there was a rumour that Wilkins was selling out the NAACP and Johnson was going to make him an American Ambassador to the Court of St James ... or was going to give him some high ... post. Roy had to get up at the Convention and deny that, and say that if Johnson ... no matter what Johnson offered him, he would not take it ... I mean the fact that the head of the organization has to get up, and he makes a spontaneous, unwritten, entirely improvised point, in which he says that he's personally hurt, personally angered ... I was on the platform at the time, right there ... that there should even be ... that this was even regarded as a possibility. It was outrageous, given his years and years, his decades of working for the organization, his whole life ... and I remember this very clearly, just as if it happened yesterday, that if he were offered a very high ... he would not take it. 'My life is with the NAACP' he says 'I will be here until God has other plans for me', something, he makes the statement to the effect that til the Lord has other plans for me, I will be here. Now the fact that that has to happen. ${ }^{82}$

Gloster Current recalled that an attorney from Flint, Michigan (the first NAACP branch to oppose the war), had given Wilkins and Washington lobbyist Clarence Mitchell a hard time by claiming that they had 'sold out' to the administration. ${ }^{83}$

${ }^{79}$ Letter, Gloster Current to Mr Locksley Edmondson, 20 Feb. I968, in NAACP papers, group IV, box $\mathrm{C}^{8}$, folder ' $\mathrm{E}$ ', Library of Congress.

80 William A. Price, 'NAACP and CORE reassess their goals', National Guardian (New York), I7July I965, p. 3 . 81 Ibid.

82 Author's interview with Herbert Hill, i6 May 2000.

${ }^{83}$ Memo from Current to Roy Wilkins, Stephen Spottswood, John Morsell, Clarence Mitchell, and Henry Moon, I4 Apr. I966, NAACP papers, group Iv box A87, folder 'Vietnam NAACP, I966-I967', Library of Congress. 
Henry Wallace, an NAACP member from Kentucky, also accused the organization of being too intimate with the Johnson administration. After the Association condemned SNCG's anti-war statement of January ig66, Wallace wrote, 'the NAACP is fast becoming the leading Uncle Tom of the civil rights movement. You are jumping through President Johnson's hoop so regularly and humiliatingly that you have become little more than an Administration houseboy. ${ }^{84} \mathrm{~A}$ few days later he wrote again to John Morsell, claiming that through its silence and its actions, the NAACP stood 'with the Johnson crowd in the current Vietnam policy. ${ }^{85}$ In May 1967, Gloster Current attended a meeting of New York branches that opposed many of the NAACP's national policies. While one of their major grievances was the Association's refusal to oppose the war in Vietnam, there was also a 'concentrated attack upon the organization for its "support of the Johnson Administration".'. Current came away from this meeting so concerned that he suggested the NAACP consider supporting Muhammad Ali's fight against the draft, since he seemed 'genuinely to be a pacifist. This certainly would be as consistent as our supporting [Adam Clayton] Powell and might confuse some who believe we are growing conservative. ${ }^{, 86}$ Eugene T. Reed, a Brooklyn-born dentist and staunch Catholic, and national board member Jack E. Tanner, perennial critics of Roy Wilkins's leadership, also alleged that the Association was too attached to Lyndon Johnson. Reed claimed that the NAACP was 'in the pocket' of LBJ, whilst Tanner charged that the I966 annual convention had been 'LBJ controlled' ${ }^{87}$

Scholars might dismiss these criticisms as the prejudices held by those who opposed Roy Wilkins, and had personal axes to grind. It is, therefore, extremely significant that senior figures within the national staff of the Association appear to have shared some of the concern over the organization's relationship with the Johnson administration. In the spring of 1966 , during an NAACP staff meeting, Gloster Current accused Wilkins of being too close to LBJ. Wilkins, unsurprisingly, took great offence: 'I consider your remark yesterday in the staff meeting to have been gratuitously insulting, with no substantive basis. In fact, you offered no citation, instance or other proof that your charge that my "closeness" to the Johnson Administration was one of the reasons for the decline in membership in the NAACP. ${ }^{98}$ The executive director denied any closeness to the administration,

\footnotetext{
${ }^{84}$ Henry Wallace to John Morsell, I3 Jan. I966, in NAACP papers, group IV box A86, folder 'Vietnam correspondence, I966', Library of Congress.

${ }^{85}$ Henry Wallace to John Morsell, i7 January I966, in NAACP papers, group Iv box A86, folder 'Vietnam Correspondence, I966', Library of Congress.

${ }^{86}$ Memorandum from Gloster Current to Roy Wilkins, I May 1967, p. I4, in NAACP papers, group IV box C24, folder 'Greenwich Village-Chelsea, NY, I966-1967', Library of Congress. My emphasis.

${ }^{87}$ See Cook, Sweet land of liberty?, p. 206; and 'Use black power, says NAACP head', Yakima Herald, I3 July 1966, in NAACP papers, group IV box AII, folder 'Board of directors, Tanner, Jack E, I966-I968', Library of Congress.

${ }^{88}$ Memorandum from Roy Wilkins to Gloster Current, 3 Mar. 1966, in Roy Wilkins papers, box 7, 'General correspondence, I966', Library of Congress.
} 
stated that no such claim had ever been made before in a staff meeting, and demanded that Current either provide evidence to support his accusation or offer an apology. Remarkably, Current's apology appears to have fallen short of a full retraction. The director of branches stated that he was sure that because the staff members knew him so well, they would not believe that he would be 'deliberately insulting to one who is doing so much for our common cause'. Current admitted that his remarks had been 'tactless' and gave an impression that 'would be difficult to substantiate'. ${ }^{89}$ Nevertheless, one is left with the distinct impression that there was considerable concern within the NAACP that the organization was tying itself too tightly to the Johnson administration.

\section{I I}

A further reason for the moderate civil rights movement's refusal to condemn the Vietnam War prior to Ig6g was anti-communism. In the early post-war period, as the chill winds of the Cold War began to blow across America, the NAACP had embraced the principal foreign and domestic tenets of anti-communist liberalism. During the late I940s and early I950s, the Association tempered its criticisms of colonialism; adopted policies designed to exclude communists or fellow travellers from the organization; and equated criticism of American foreign policy with pro-communism. ${ }^{90}$ Indeed, not only did the NAACP support American efforts to 'halt Communist aggression' in Korea, ${ }^{91}$ the organization also attacked the domestic peace movement:

we warn our branches and youth councils against so-called 'peace' organizations that have in the forefront of their program the demand to 'bring back our boys from Korea.' Such peace organizations are not only urging a policy desired by the communist bloc of nations, but one likely to cause more and bigger wars throughout the world by making aggression in Korea successful. ${ }^{92}$

The NAACP's reaction to the Vietnam War and the peace movement that it spawned would be shaped by, and would reflect, the anti-communist liberalism that the organization had adopted during the late i940s. The NAACP leadership, along with the majority of Americans, would prove incapable of conceiving

${ }^{89}$ Memorandum from Gloster Current to Roy Wilkins, 3 Mar. I966, in Roy Wilkins papers, box 7 , 'General correspondence, ig66', Library of Congress.

${ }^{90}$ See 'NAACP stand on colonialism and U.S. foreign policy', Crisis, 62 no. I (Jan. I955), p. 23; Charles W. Cheng, 'The Cold War: its impact on the black liberation struggle within the United States', Freedomways: A Quarterly Review of the Freedom Movement, I3 no. 3 (I973), pp. I96-7. At the I950 NAACP annual convention, the Association passed a resolution against communist infiltration - see Berg, 'Guns, butter, and civil rights', p. 215; Adam Fairclough, 'Race and red-baiting', in Jack E. Davis, ed., The civil rights movement (Malden, MA, and Oxford, 200I), p. 98; and Gerald Horne, Black and red: W. E. B. Du Bois and the Afro-American response to the Cold War, I944-1963 (Albany, NY, I986), pp. $5^{\mathrm{O}-6 .}$

91 NAACP board meeting, I3 Nov. I950, quoted in Horne, Black and red, p. I29.

92 Quoted in 'NAACP stand on colonialism and U.S. foreign policy', Crisis, 62 no. I (Jan. I955), p. 25 . 
that the anti-Vietnam War movement could be anything other than communistinfluenced.

In April 1965, the Flint, Michigan, branch of the NAACP became the first to engage with the Vietnam War when it passed a resolution urging a withdrawal of American troops. ${ }^{93}$ Although the national office acted quickly to stifle this protest, the Association's leadership interpreted such signs of dissent as the product of an organized left-wing insurgency ${ }^{94}$ Gloster Current, NAACP director of branches and a staunch anti-communist, wrote that the 'left-wing ... is having a field day! Its most recent project is to create problems over our country's Vietnam policy.' He cited Flint as a case in point, and warned that the Association had to take decisive action to prevent local branches getting involved in 'left-wing shenanigans ${ }^{95}$ Current, who had been active in the Detroit branch of the NAACP before being promoted to the national office in 1946 , presided over the functioning of the organization's I, 400 branches. The Methodist and former jazz musician was, according to colleague Herbert Hill, 'the bureaucrat incarnate' (he had received a master's degree in public administration from Wayne State University) and he guarded his NAACP turf resiliently. James Farmer, who served briefly as the Association's activities co-ordinator, recalled Current telling him that 'I co-ordinate the activities of our branches, and $I$ am the director of their programs.' The director of branches was a committed anti-communist who remained suspicious of the more radical wing of the freedom struggle. In February 1968, for example, he referred to Stokely Carmichael and H. Rap Brown as 'nuts' and declared that 'it would really be worth our while if we could squelch these do-nothing negativists ... because they are standing in the way of progress ${ }^{96}$ Herbert Hill believes that Current's zealous anti-communism was largely the result of his bureaucratic mind-set. Current, whom Hill describes as a 'wonderful human being' but 'not very politically sophisticated', viewed the Communists as a threat to the organization - they were an alien force who were not loyal to the NAACP. The director of branches merely responded to protect the Association. Hill claims that Current would have done the same if the 'Episcopalian Church were coming in' - 'his job was to protect the internal integrity of the NAACP. He wasn't going to let anybody gain control of the branches ... he did what he thought he had to do. ${ }^{, 97}$

The NAACP leadership was concerned that attempts would be made at the I965 annual convention to get the organization involved with anti-war protests. Such attempts were viewed as the work of a left-wing conspiracy. Current

${ }^{93}$ Berg, 'Guns, butter, and civil rights', p. 215.

${ }^{94}$ NAACP papers, group III box A328, folder 'Vietnam War, I964-1965', Library of Congress.

${ }_{95}$ Memo from Gloster Current to NAACP staff, 22 Apr. 1965, NAACP papers, group III box A328, folder 'Vietnam War, I964-1965', Library of Congress. See also Berg, 'Guns, butter, and civil rights', p. 215 .

${ }^{96}$ Letter, Gloster Current to Locksley Edmondson, 20 Feb. 1968, in NAACP papers, group Iv box c58, folder ' $\mathrm{E}$ ', Library of Congress.

${ }^{97}$ Author's interview with Herbert Hill, 9 Aug. 2000. 
explained that 'we certainly will have left-wingers raising issues in the Resolutions Committee', although he also recognized that 'there are many others who are not left-wingers, but who have genuine reservations about Vietnam and the Dominican Republic'. Current suggested that key staff members should get together to take advance action to strengthen control over convention proceedings. ${ }^{98}$

The following year the NAACP leadership again worried about what they viewed as an organized left-wing insurgency designed to cause problems at the Los Angeles convention over Vietnam. Current explained that:

While we have successfully evaded tying civil rights to the peace issue, there is evidence that the left wing is at work to influence our resolutions to be adopted in Los Angeles ... The left wing is coming out of the woodwork, and the Vietnam issue could well be the biggest problem we will be confronted with in Los Angeles. ${ }^{99}$

Current's obsession with communism also coloured his interpretation of the Spring Mobilization in April i967. He attended the massive demonstration in New York City where he heard black leaders including Stokely Carmichael, Floyd McKissick, and Martin Luther King attack the Vietnam War. Current concluded that 'the entire performance was reminiscent of the 3 os when the commies harangued a crowd with certain well-chosen speakers'. He also warned the NAACP national staff that:

Whether we wish to acknowledge it or not, we have a resurgence of the left such as we have not had since World War II. NAACP branches are going to be invaded and urged to get aboard the peace movement ... We need to mount an offensive to give the American people the facts and to urge youth and Negroes in the communities to pay no attention to the fools. There ought to be an off-the-record meeting of the Negro press and key well chosen Negro leaders to decide how to deal with what seems to be in the offing. ${ }^{100}$

Fears that Vietnam might wreak havoc within the Association persisted. Current added a new set of miscreants to his cast of villains when he informed the national staff that they should be prepared for the efforts of 'peace-niks, militants and ... odd balls', as well as leftists, to ruin the ig67 convention. ${ }^{101} \mathrm{He}$ warned branch officials to keep their eyes open for people stirring dissent and to report them to the national staff. Current also asked the branch officers to 'urge delegates not to be taken in by those who would seek to turn the NAACP into another extremist organization'. ${ }^{102}$

98 Gloster Current memo to Roy Wilkins, John Morsell, Clarence Mitchell and Henry Moon, I4 May I965, in NAACP papers, group III box A20, folder ' 1965 resolutions', Library of Congress.

${ }^{99}$ Memo from Current to Roy Wilkins, Stephen Spottswood, John Morsell, Clarence Mitchell, and Henry Moon, I4 Apr. I966, NAACP papers, group IV box A87, folder 'Vietnam NAACP, I966-I967', Library of Congress.

100 I6 Apr. I967 memo from Current to Spottswood, Mitchell, Moon, Morsell et al., p. 4, NAACP papers, group IV box A87, folder 'Vietnam NAACP, I966-I967', Library of Congress.

101 2 I June ig67 memo, Current to all staff members, NAACP papers, group IV box C24, folder 'Greenwich Village-Chelsea, NY, i966-I967', Library of Congress. $\quad{ }^{102}$ Ibid. 
Anti-communism also affected the way in which the NAACP viewed the domestic peace movement, and the Association was not afraid to share its views. Indeed the organization, from the earliest opportunity, red-baited the anti-war movement. Writing in the New York Post in July 1965, Roy Wilkins referred to the role of Martin Luther King's 'aides' in his decision to urge a negotiated peace in Vietnam. He then went on to explain that, while in a broad sense all men were brothers, Chinese Premier Chou En Lai was 'no close relative. At least, he and his are not close enough for me to ease my fight here against racial bigotry in order to enter into a foreign policy matter that seems to be of more than passing interest to Communist China. ${ }^{103}$ After SNCG released its anti-war statement in January I966 Wilkins responded with a newspaper column claiming that it was following the 'official leftist line' ${ }^{104}$

Support for the Cold War also resulted in much of the NAACP national leadership viewing the Vietnam War as a just cause. Anti-communism blended with patriotism, with the result that although the Association took no official policy on the conflict, its leaders were less inclined to be sympathetic to the antiwar movement's claims that America was intervening in a civil war under the guise of preventing communist aggression. Herbert Hill acknowledged that most of the Association's leadership adhered to the traditional Cold War arguments, 'I think with very few exceptions they bought all of that, yeah. They were Cold Warriors. ${ }^{105}$

\section{I I I}

Until the spring of 1967 , as Manfred Berg has noted, there was little organized opposition within the NAACP toward the 'no position' stance on Vietnam. ${ }^{\mathbf{1 0 6}}$ However, this does not mean that the Association's policy went unchallenged. It is very difficult to gauge the extent of opposition to the war within the NAACP, but it is clear that there were many members who not only opposed the war personally, but also worked to generate opposition to the war within the Association. Although such activity was limited, its very existence helps to counter the notion of a single, monolithic NAACP. Often local branches could be more radical, and more flexible, than the national office in New York City. Moreover, anti-war sentiment within the NAACP during this period helps to explain its later decision to oppose the war.

As Berg has documented, the first sign of organized opposition to the war within the NAACP came from the Flint, Michigan, branch in the spring of I965. ${ }^{107}$ On Io April, the branch's executive board adopted a resolution urging

${ }^{103}$ Roy Wilkins, 'Sidetrack', New York Post, I8 July 1965, Roy Wilkins papers, box 39, folder 'Newspaper clippings, I $964^{-1965}$ ', Library of Congress. My emphasis.

104 'SNCG's foreign policy', New York Post, i6 Jan. I966, Roy Wilkins papers, box 39, folder 'Newspaper column clippings, I966', Library of Congress.

105 Author's interview with Herbert Hill, I6 May 2000.

${ }^{106}$ Berg, 'Guns, butter, and civil rights', p. 22I.

${ }^{107}$ Ibid., p. 215. 
LBJ to use his influence to mediate the 'civil war' in Vietnam and arrange negotiations between South Vietnam's government and the Viet Cong. The resolution also called for American troops to be withdrawn immediately. ${ }^{108}$ At the I965 annual convention, held in Denver, an attempt was made to force Vietnam on to the agenda, and delegates from Flint played a role in the effort to persuade the Resolutions Committee to consider an anti-war resolution. The political and organizational machinations of the NAACP bureaucracy ultimately helped to ward off this threat. Herbert Hill candidly explained that the NAACP staff 'understood' that the anti-war resolutions which invariably came up at conventions would not be allowed to get to the floor, since the Resolutions Committee was easy to manipulate - 'the NAACP was a very democratic institution ... it was, in terms of structure and forms. The conventions were very democratic. On the other hand ... like all democratic institutions there is bureaucratic control. ${ }^{109}$ One report of the convention explained that 'the closed operation of the Resolutions Committee was likened to that of a "Star Chamber"; delegates complained that they could not tell what was going on'. One delegate claimed that 'if the membership had not been so restricted by organization they might have been more progressive'. ${ }^{110}$ Hill is less sure that the delegates would have voted in favour of the NAACP taking an anti-war position during this period. While he believes that a majority of convention delegates in the mid-ig6os might have opposed the war he thinks that there would still have been a majority favouring the no position approach:

there were two questions, and in fact it was clear to everybody ... most of the rank and file delegates, were interested in stopping the war ... because black people were disproportionately paying a very high price. That's question number one. And on that question I think it would have been an affirmative answer. There's an opposition to the war, let's get the hell out. It's stupid ... black people are dying. But if there's another question, simultaneously, is it in the interests of the NAACP and of the black community to take a position, here I think it would have been very close. Quite possibly the majority would have said we should have no position. There were two separate questions. Are we in opposition to the war? Yes. Is it in our interest for the Association ... to take a position, then I'm not so sure ... I think if it had have been put the second way, it is quite possible it would have failed. ${ }^{111}$

A number of NAACP people were active in various peace campaigns during the mid-rg6os. Robert Scheer, who ran against Jeffrey Cohelan in California's seventh congressional district in I966, was supported by Carlton Goodlett and Dr Thomas Burbridge - both former presidents of the San Francisco NAACP. ${ }^{112}$

${ }^{108}$ Flint, Michigan, resolution, Io Apr. I965, NAACP papers, group III box A328, folder 'Vietnam War, I964-1965', Library of Congress. $\quad{ }^{109}$ Author's interview with Herbert Hill, r6 May 2000.

110 'NAACP convention: some members complain about "restrictions"', Movement (Aug. 1965), p. 6.

111 Author's interview with Herbert Hill, I6 May 2000.

112 For a detailed account of this campaign see Serge Lang, The Scheer campaign (New York, 1967); George Kaufmann, 'Condemn war and ghettos', Berkeley Barb, 2 no. 3 (2 I Jan. I966), p. I ; finding aid, Carlton B. Goodlett papers, $194^{2-67}$, SHSW. 
In New York's 26th congressional district Leslie Roberts was campaigning for election. The forty-four-year-old Jamaican immigrant, a local NAACP activist, was the first African American to seek congressional nomination in Westchester. ${ }^{113}$ He opposed the war and argued for negotiations with the Viet Cong. Roberts's campaign literature emphasized Vietnam's negative effects on the war on poverty - 'you can drive through the streets of Westchester any day of the week and see casualties of the Vietnam War. Those families living in the peeling old houses with no toilets or hot water, they're Vietnam casualties. Those men standing on street corners with no jobs, no training, no hope - they're Vietnam casualties. ${ }^{114}$ In I968, NAACP field secretary Charles Evers ran for Congress in Mississippi's third district. The brother of the martyred Medgar had been a bootlegger and petty criminal in Chicago before heading to the Magnolia State to become the Association's first self-appointed field secretary, and he remained a divisive and controversial figure. ${ }^{115}$ Evers declared 'I am against the war. I will not have our people fight for someone else's freedom when they are going to have to come home and have to fight in this country for their own freedom ... I am also against our lily-white draft boards and will see that the boards are made representative of all the people. ${ }^{116}$

There was also anti-war activity in some NAACP branches. In the spring of I966, for example, members of the Lunenburg County (VA) branch were 'disturbed about the expanding war in Vietnam and the consequence it might have on the Federal government's domestic program'. ${ }^{117}$ The leading opponent of the Vietnam War within the NAACP was the Greenwich Village (NY) branch. In February I966, it decided to hold a forum to discuss the links between the peace and civil rights movements, but the NAACP national office had requested that this be cancelled. ${ }^{118}$ At the 1966 and 1967 conventions, the Greenwich Village branch sought to introduce anti-war resolutions. ${ }^{119}$

Evidence of serious dissent with the Association's Vietnam policy did not surface until the autumn of I967. In October, the Michigan State Conference adopted an anti-war resolution. The resolution noted the war's detrimental effect on the anti-poverty programmes, the high numbers of black casualties, and the reluctance of the South Vietnamese Army to fight; and it called for an unconditional bombing halt and a gradual de-escalation of the war. ${ }^{120}$ Later that

\footnotetext{
113 See Roberts's campaign material, National Coordinating Committee to End the War in Vietnam records, I964-7, series I, box 4, folder 'Peace candidates, I966', SHSW. $\quad{ }^{114}$ Ibid.

115 See Payne, I've got the light of freedom, pp. 360-I; and Dittmer, Local people, p. I78.

116 Mississippi Freedom Democratic Party (MFDP) newsletter, vol. 2 no. 6 (c. Feb. I968), SHSW.

117 The New Virginia newsletter, vol. 2 no. I (Mar. I966), SNGG records, reel 44, Library of Congress.

118 Advance, 6 no. 4 (I966), p. I, in NAACP papers, group IV box J7, folder 'Printed matter NAACP by states, New York - NYC - Greenwich Village, I966-I967', Library of Congress.

119 NAACP papers, group Iv box A87, folder 'Vietnam NAACP, I966-I967', Library of Congress; and Berg, 'Guns, butter, and civil rights', p. $22 \mathrm{I}$.

120 Io Oct. I967, Current memo to Dr John Morsell - copy of resolution on Vietnam adopted by Michigan State Conference, in NAACP papers, group IV box A87, folder 'Vietnam NAACP, ı966-ig67', Library of Congress.
} 
month, largely due to the efforts of younger activists, the New York State NAACP adopted an anti-war resolution during a stormy session at its convention. Initially, older NAACP members had blocked attempts to oppose the war. But nineteenyear-old Gerald Taylor led the youth contingent in an eighteen-minute demonstration that forced the issue on to the floor. Ultimately, the delegates voted by I07 to 72 to ask the NAACP national board of directors to 'use its good offices to urge an immediate termination of hostilities in [Vietnam]' ${ }^{121}$ Often there was a generational element to anti-war feeling within the Association. In New Orleans, the local NAACP Youth Council had supported King's Riverside Speech, and the group's twenty-one-year-old vice-president, Raymond DuVernay, had been jailed that February for draft resistance. ${ }^{122}$ Furthermore, in early 1967 , the NAACP's Youth and College Division had called for a system of voluntary national service as an alternative to the 'unjust' draft. ${ }^{123}$

\section{IX}

Although the policy of treating civil rights and Vietnam as distinct and unconnected issues was upheld until I969, it was weakened by a number of factors. First, the claim that foreign policy issues lay outside the NAACP's gamut was, in fact, incongruous with the Association's history. Throughout its existence the NAACP had engaged with international affairs and debated the nature of America's role in the world. Early leaders of the Association, such as Moorfield Storey and Oswald Garrison Villard, had frequently spoken out against American foreign policy; and the organization had sometimes adopted criticial positions. ${ }^{124}$ For example, in 1915 the Association had condemned the American occupation of Haiti. The NAACP also spoke out against the Italian invasion of Ethiopia in 1935, and for most of the I940s it had consistently passed anti-colonial and antiimperialist resolutions. ${ }^{125}$ As one history teacher at Michigan State University

121 See Thomas A. Johnson, 'State's NAACP opposes the war and new charter', New York Times, 23 Oct. I967; Carolyn Dixon, 'NAACP youths "rough", , New York Amsterdam Neres, 28 Oct. I967; and Advance, 6 no. 27 (I967), p. 4; NAACP papers, group Iv box J7, folder 'Printed matter NAACP by states, New York - NYC - Greenwich Village, I966-1967', Library of Congress.

122 DuVernay had refused to be a 'black mercenary for white imperialism', see 'Many challenge war, draft', Southern Patriot, Feb. I967, p. 8.

123 Adam Fairclough, Race and democracy: the civil rights struggle in Louisiana, 1915-1972 (Athens and London, I995), p. 4I7; and NAACP News, Feb. I967, in NAACP papers, group IV box JiI, folder 'Printed matter - west coast regional office newsletters, I966-April, I967', Library of Congress.

${ }^{124}$ See letter from William B. Hixon, Jr, to the New York Times, dated ro Apr. I967, reprinted in $D r$ Martin Luther King, Dr Fohn C. Bennett, Dr Henry Steele Commager, Rabbi Abraham Heschel speak on the war in Vietnam - with an introduction by Dr Reinhold Neibuhr, p. 29, in Records of the Southern Christian Leadership Conference, 1954-1970, Part 4: Records of the Program Department (microfilm edition), editorial adviser Cynthia P. Lewis (University Publications of America, I995), reel 26, series VII, records of the Peace Education Project, I966-7 cont., box I76, folder 8 'Vietnam summer, I967-I968', Library of Congress.

${ }^{125}$ See Leon D. Pamphile, 'The NAACP and the American occupation of Haiti', Phylon, 47 no. I (I986); David Levering Lewis, W. E. B. Du Bois, biography of a race, I868-I9I9 (New York, I993), p. 522 ; Brenda Gayle Plummer, Rising wind: black America and U.S. foreign affairs, 1935-196o (Chapel Hill and London, I996), pp. 40-5I ; and Horne, Black and red, pp. 20, 21, and 26. 
explained in a letter to the New York Times, 'it has been forgotten that the precedent of a civil-rights organization ... criticizing American foreign policy, was not set by Stokely Carmichael ... but by the NAACP' ${ }^{126}$ After the organization's shift to anti-communism at the end of the I940s, foreign policy still remained an area of concern - the NAACP passed a resolution supporting American actions in Korea at its I95I annual convention, for example. ${ }^{127}$ While Roy Wilkins and other NAACP leaders may have stated that foreign policy and civil rights should not be mixed, they cannot but have been aware of the history of their own organization. It was a history that suggested exactly the opposite.

The policy was further undermined by the fact that, on occasion, the NAACP came close to full public support for the war. ${ }^{128}$ In December 1965 , replying to a critic of the NAACP's Vietnam stance, John Morsell explained that he was 'thoroughly convinced of the righteousness of the objective'. ${ }^{129}$ In January I966, Roy Wilkins expressed support for the Johnson administration's Vietnam policy when he wired Lyndon Johnson that 'your call for carrying on domestic crusade for the Great Society projects including all aspects of anti-poverty program along with fulfilling our nation's commitment in Vietnam is the right call and is a challenge to every American'. ${ }^{130}$ In the spring of I 967 the NAACP's executive director offered a partial endorsement of the war effort:

I don't speak as a hawk or a dove ... But, is it wrong for people to be patriotic? Is it wrong for us to back up our boys in the field ... They're dying while we're knifing them in the back at home ... Maybe I'm a bit old fashioned ... maybe we are wrong, maybe we shouldn't be in Vietnam. But when you're out there in the trenches being fired at, you have to fight back. ${ }^{131}$

Some critics believed that, in travelling to Vietnam in July i966, Whitney Young had given implicit endorsement to the war, whilst others accused him of being a tool of the Johnson administration. ${ }^{132}$ Cecil B. Moore, the militant head of the Philadelphia NAACP, for example, bitterly denounced Young and claimed that he had been used to 'whitewash' racial discrimination in Vietnam. ${ }^{133}$ But, the following year, the Urban League's executive director explicitly flouted the policy of keeping civil rights and Vietnam separate. During the summer of 1967 Young appears to have experienced a wobble over his support of the guns and butter policy. At the NUL national conference, held in Portland, Oregon, at the end of August, Young explained that he was no longer sure that it was possible to

\footnotetext{
126 See letter from William B. Hixon, Jr, to the New York Times, dated io Apr. I967, in SCLC records, part 4, reel 26, Library of Congress.

127 Quoted in 'NAACP stand on colonialism and U.S. foreign policy', Crisis, 62 no. I (Jan. I955), p. 25 . 128 See Berg, 'Guns, butter and civil rights', p. 220.

129 Letter, John Morsell to Henry Wallace, Io Jan. I966, pp. I-2, NAACP papers, group IV box A86, folder 'Vietnam correspondence, I966', Library of Congress.

130 i3 Jan. I966, telegram from Roy Wilkins to LBJ, WHCF name file - Roy Wilkins, LBJ. See also Berg, 'Guns, butter, and civil rights', p. 220, my emphasis.

131 'Wilkins raps King's civil rights policy', Worcester Sunday Telegram, I9 Apr. I967, NAACP papers, group IV box A86, folder 'Vietnam correspondence, I967-I968', Library of Congress.

${ }^{132}$ Dickerson, Militant mediator, pp. 270 and 27I-3. $\quad{ }^{133}$ Ibid., pp. 273-4.
} 
have both guns and butter, and that if it came to a choice, 'the first priority ought to be peace and justice here at home'. ${ }^{134}$

It was after this wobble that President Johnson telephoned Young to tell him that he wanted him to be part of the American delegation to observe the elections in South Vietnam. Young was reluctant to go but was faced with little choice after LBJ applied some of his infamous treatment - 'Whitney, you wanted a Negro on the Supreme Court and I put on one ... Now I want a Negro on this group going to Vietnam ... Well Whitney, I'm going to announce you as one of the team, and if you feel you can't serve your country, you explain it to the press. ${ }^{\mathbf{1 3 5}}$ Andrew Young believed that Young had been tricked into supporting the administration and, confirming the wobble theory, suggested that the NUL executive director had been experiencing 'inner conflict' over the Vietnam War. ${ }^{136}$ It is likely that Marcia Young's opposition to the Vietnam War contributed to this inner turmoil. Young's eldest daughter, a student at Bryn Mawr College, engaged in a hunger fast as part of her anti-war protests. ${ }^{\mathbf{1 3 7}}$

In accepting this mission, albeit reluctantly, Young became a 'significant participant in a major foreign policy matter', and seriously compromised his position of neutrality regarding the war itself. The twenty-two-man US delegation, that included senators, governors, mayors, churchmen, businessmen and labour leaders, arrived in Saigon on Wednesday, 3o August. Young made the journey aboard Air Force One carrying serious concerns about the war. ${ }^{138}$ However, he returned impressed with the election effort in South Vietnam, which had taken place under unusual and difficult circumstances. ${ }^{139}$ Young had been particularly struck by the South Vietnamese enthusiasm for the elections - in which South Vietnam's military leaders, Nguyen Cao Ky and Nguyen Van Thieu, claimed victory with 35 per cent of the vote. The election observers ignored charges that major opponents of the Thieu-Ky regime had been prevented from running or had been jailed, as well as reports of voter intimidation and fraud, to declare that the elections had been 'reasonably efficient, free, and honest'. ${ }^{140}$ At an hour-long debriefing with the president in September, Young declared that he was 'completely satisfied that these were free elections as well as could be expected under the conditions'. He also stated that America might learn some lessons from South Vietnam's version of democracy - such as allowing eighteen-year-olds to vote. ${ }^{\mathbf{1 4 1}}$ But perhaps it was another observer, John Knight

134 Weiss, Whitney M. Young, Fr., p. I6r.

135 Ibid., p. I62. LBJ was referring to the recent appointment of Thurgood Marshall to the US Supreme Court.

136 Andrew Young, An easy burden: the civil rights movement and the transformation of America (New York, I996), p. 43I.

137 Ibid., p. 43I; and Weiss, Whitney M. Young, Fr., p. I68.

138 Weiss, Whitney M. Young, Fr., p. I62. 139 Ibid.

140 Dickerson, Militant mediator, pp. 278-9.

141 Diary backup, box 75, 6 Sept. I967, memo from Jim Jones to LBJ, 6 Sept. I967, subject: meeting with Vietnam election observers in the cabinet room (meeting lasted from Ir:o9 a.m. to I2:05 p.m.), p. 3 , LBJ. 
of Knight Newspapers, who best exemplified the US government's attitude toward democracy in South Vietnam. Addressing concerns about the repression of political opponents during the elections, he told Johnson that he had 'sought out dissidents such as the suspended editors and the candidates who were not permitted to run and he heard them out thoroughly and fully and at the close he had the opinion that he would not want them running his country'. ${ }^{142}$

In joining the American delegation to observe the South Vietnamese elections, Whitney Young had stretched the policy of treating civil rights and Vietnam as unconnected issues to breaking point, and in the process severely compromised his own neutrality over the war. ${ }^{143}$ Young had moved beyond using Vietnam for the purposes of gleaning domestic political concessions to become a reluctant supporter of the Johnson Administration's foreign policy. SNCC's John Wilson described the Urban League leader as a 'puppet' of the American government, and claimed that ' [Young] was used by the US government to make those [South Vietnamese] elections appear legitimate in the eyes of black people. ${ }^{, 144}$

\section{$\mathrm{X}$}

From i969, the moderates' position on the war changed from one of 'golden silence' to cautious opposition. Richard Nixon's election to the presidency in November 1968 made it easier for them to oppose Vietnam. Although revisionist historians have attempted to paint Nixon as a progressive on the race question, most black leaders at the time viewed him as at best unsympathetic to their cause, and at worst a disaster for it. ${ }^{145}$ Nixon's attempts to end the war in Vietnam by winning it also generated a good deal of dovish outpouring from the Democratic Party. The need for black leaders to maintain silence on the war in order to promote the coalition strategy quickly evaporated. Moreover, from i968, anti-war sentiment itself moved from the radical fringe to the mainstream - aided by the presidential campaigns of Robert Kennedy and Eugene McCarthy; the growth of anti-war sentiment among liberal Democrats and moderate Republicans; and the emergence of a liberal, respectable anti-war movement.

Anti-war moderates recognized that the peace movement's 'melange of Maoism and Stalinism with Negro nationalism' had resulted in it being one of the few things in America that was more unpopular than the war itself. ${ }^{146}$ Draft card burnings, revolutionary rhetoric, counterculturalism, and anti-Americanism had

${ }^{142}$ Ibid., p. 4, LBJ.

${ }^{143}$ For example, after returning from observing the elections, the Johnson administration tried to involve Young in efforts to justify the war. He was sent a speech written by a presidential aid to help him gain a 'better understanding of the Government's position and the steps that led to our present involvement in Vietnam', see Dickerson, Militant mediator, p. 280.

${ }^{144}$ Statement by John Wilson in Bratislava, Cz. Conference between Vietnamese and Americans. (summer/August 1967), p. 4, SNCC records (microfilm edition), reel 23, Library of Congress.

${ }^{145}$ See Joan Hoff, Nixon reconsidered (New York, I994); and Dean J. Kotlowski, Nixon's civil rights: politics, principle, and policy (Cambridge, MA, 2002).

${ }^{146}$ I. F. Stone's Weekly, 28 June i965, p. I, quoted in David Cochran, 'I. F. Stone and the new left: protesting U.S. policy in Vietnam', Historian, 53 (1991), p. 517. 
done little to endear the peace movement to mainstream America. ${ }^{147}$ By the late I96os, there were growing numbers of anti-war activists arguing for a change in focus and tactics on the part of the peace movement, in order to make it more effective. Many of these forces came together in the Vietnam Moratorium Committee (VMC), which was founded in the summer of ig69. ${ }^{148}$

Although VMC members opposed the war in Vietnam, they still believed in working within the two party system. Sam Brown, veteran of the McCarthy campaign and VMC co-ordinator, understood that potential peace supporters were put off by long hair, campus protest, and 'anything which irritates the nerve endings of middle-class values', and that when the Silent Majority were pitted against the radicals there could only ever be one winner. ${ }^{149}$ The Moratorium believed that 'only a peace movement which reaches Richard Nixon's constituency can stop it'. ${ }^{150}$ The organization hoped to move the anti-war movement beyond its student base, which it considered to be ineffectual, and to nurture a new peace leadership composed of 'Senators, Congressmen, governors, mayors, businessmen - all the straight people who are willing to make a firm and unequivocal commitment against the war. ${ }^{151}$

The VMC's efforts received support from the moderate wing of the civil rights movement. During 1967, Whitney Young had set aside his concerns about Vietnam to offer a virtual endorsement of the war when he travelled to South Vietnam to observe the elections. Yet, in the aftermath of the Tet offensive and LBJ's withdrawal from the presidential race, Young re-evaluated his opinion of the war in light of the continued suffering in Southeast Asia, and his doubts re-surfaced. He came to believe that Martin Luther King had been 'more right' about the war than he; and, perhaps freed politically now that a Republican occupied the White House, felt able to express his concerns publicly. ${ }^{152}$ There was also pressure from below - in a meeting with Urban League trustees on 7 October I969, Young spoke of the 'terrific pressure' from the 'black community', youth and white liberals for the organization to take a position against the war. ${ }^{153}$

Although Young was unable to accept an invitation to speak at the I5 October anti-war rally in Washington DC, he did release a statement. ${ }^{154}$ In it Young explained that he had, for some time, been viewing America's 'agony in Vietnam with a sense of deepening distress'. He went on to declare that:

I am totally convinced that this war has an extra dimension for black people that it does not have for many whites. We are suffering doubly. We are dying for something abroad that we do not have at home.

${ }^{147}$ See William R. Berkowitz, 'The impact of anti-Vietnam demonstrations upon national public opinion and military indicators', Social Science Research, 2 (1973); E. M. Schreiber, 'Anti-war demonstrations and American public opinion on the war in Vietnam', British fournal of Sociology, 27 (1976); and Robert E. Lane and Michael Lerner, 'Why hard-hats hate hairs', Psychology Today (New York) (Nov. 1970), p. 45.

${ }^{148}$ Francine de Plessix Gray, 'The moratorium and the new mobe', New Yorker, 3 Jan. I970.

${ }^{149}$ Sam Brown, 'The politics of peace', Washington Monthly, 2 (1970), pp. 26 and 44.

${ }^{150}$ Ibid., p. 25. $\quad{ }^{151}$ Ibid., p. 45. $\quad{ }_{152}$ Dickerson, Militant mediator, p. 282.

153 Ibid., p. 28I. $\quad{ }^{154}$ Weiss, Whitney M. Young, Fr., p. I94. 
I am further convinced that the most effective way for America to win credibility as a democracy in the eyes of the world is through the immediate resolution of its domestic crisis rather than through expansion of its defense capability. ${ }^{155}$

Using language that was reminiscent of Martin Luther King's, Young charged that the Vietnam War had 'twisted America's soul', before concluding with a demand for an 'immediate termination' of the conflict. ${ }^{\mathbf{1 5 6}}$

Support also came from the NAACP. With anti-war feeling rising among the American population, with the emergence of a respectable anti-war movement, and with the election of Nixon, peace advocates were able to prosper within the NAACP for the first time. At the Association's 6oth annual convention, held in Jackson, Mississippi, anti-war sentiment finally began to flourish. On I July, at the annual Minister's Breakfast, Los Angeles clergyman Rev. Thomas E. Kilgore, president of the American Baptist Convention, told his audience that 'our values are inverted ... we cannot go on killing in Vietnam'. ${ }^{157}$ While the NAACP delegates reaffirmed that the Association was primarily a civil rights organization, they also noted that 'billions of dollars are being spent in a cruel, inhuman, and unjust war in Vietnam', and called upon the United States government to 'institute the speediest measures to withdraw American troops from Vietnam and concentrate our wealth and skills on peaceful measures to prosecute our own domestic war on poverty'. ${ }^{158}$ It was within this context that the NAACP came to offer limited support to the VMC. In October, James Blacke, national vicepresident in charge of youth affairs, agreed to send out a mailing urging full support of the Moratorium. In his capacity as an NAACP official, Blacke also endorsed a statement that called for an immediate cease-fire and 'prompt' withdrawal of American soldiers from Vietnam. ${ }^{159}$

\section{I}

Despite these developments, the moderate civil rights movement never participated in anti-war activities with any great enthusiasm. Whitney Young's untimely death in March I97I perhaps prevented greater involvement, but the NAACP remained reluctant to devote time and energies to the struggle for peace. In January I97I, for example, Jerry Gordon of the National Peace Action Coalition (NPAC), a major anti-war organization, wrote to Roy Wilkins requesting NAACP endorsement of the forthcoming anti-war actions. One might have expected the Association to respond positively. Not only had it adopted an anti-war position, but the NAACP was also a staunch opponent of the Nixon Administration. ${ }^{\mathbf{1 6 0}}$

155 NUL press release, I3 Oct. I969, in Vietnam Moratorium Committee (VMC) records, box 4, folder 6. 'Statement by Whitney M. Young, Jr., on Vietnam', p. 2, SHSW. $\quad{ }^{156}$ Ibid.

157 NAACP annual report, I969, p. I47. $\quad{ }^{158}$ Ibid., p. I55

159 VMC records, box 4, folder 6, 'National youth leaders endorse moratorium', press release, i Oct. I969, SHSW.

160 At its June I970 convention, NAACP chairman Bishop Stephen Spottswood had declared that 'this is the first time since I920 that the national administration has made it a matter of calculated 
Despite these developments, Wilkins refused to give organizational support to the peace movement. Although he wrote to Gordon that 'we, too, believe that the war ought to be brought to a rapid close and share your concern about its re-escalation', the NAACP executive director explained that the Association would be unable officially to endorse the anti-war actions as it was concentrating on a membership drive, and Wilkins feared that anti-war activities would prove a distraction. ${ }^{161}$ Wilkins's decision did not, however, prevent NAACP participation in the massive 24 April rally, held in Washington, DC - which was endorsed by Lonnie King, president of the Atlanta NAACP; Kate Moore, of the NAACP national staff; and the Detroit NAACP among others. ${ }^{162}$

There were a number of reasons why the moderate wing of the civil rights movement did not participate enthusiastically in the peace movement, even after they adopted an anti-war stance. First, securing advances for black Americans remained the raison d'être of groups like the NAACP. The Greenwich Village branch, which had been one of the fiercest critics of the 'no position' policy in the mid-ig6os believed that the Association had to 'keep its eye on the main emphasis ... the ongoing fight for first-class citizenship' for non-white Americans. ${ }^{163}$ Despite the efforts of some radical peace organizations, the antiwar movement never transformed itself into a multi-issue coalition seeking fundamental change to the American socio-economic and political system. The peace movement's use of rhetoric that appealed to blacks did not disguise the paucity of tangible action on behalf of Afro-America. Roy Wilkins's complaint that the anti-war movement was manipulating African Americans 'for the benefit of causes connected only in an oratorical fashion to Negro jobs, schools, voting and slums here at home' had a good deal of merit. ${ }^{164}$ As the radical Guardian newspaper editorialized in February 1970, 'an antiwar movement which ... only gives token support to 23 million blacks ... cannot expect black Americans to enlist in the actions of the antiwar coalitions'. ${ }^{165}$

Second, there was not enough pressure from below to force the moderates to involve themselves more fully in anti-war activities. Most members of groups like the NAACP and the Urban League reflected the feelings of most Americans who opposed the war in Vietnam but did not take to the streets to demand a US

policy to work against the needs and aspirations of the largest minority of its citizens'. See 'NAACP sternly critical of Nixon administration', Guardian, i July I97o, p. 4.

${ }^{161}$ Letter from Jerry Gordon to Roy Wilkins, 22 Jan. 1971, and Wilkins's reply of I Feb., National Peace Action Coalition records, reel 4 , SHSW.

162 'Preliminary endorsers of the April 24th march on Washington, D.C. and San Francisco for the immediate withdrawal of all U.S. forces from South East Asia', George Wiley papers, box 32, folder 3 , SHSW.

${ }^{163}$ NAACP papers, group vI, box CI74, folder 'Branch development, newsletters, New York, 1969', Advance, 7 no. 50 (1969), Greenwich Village-Chelsea branch, p. 4- 'President's corner', Library of Congress.

${ }^{164}$ Roy Wilkins, 'LBJ's programs would aid negro', Detroit Newes, 26 Aug. 1967, office files of Frederick Panzer, box $33^{1}$, folder - civil rights $1967-8$, LBJ.

165 'Vietpoint', Guardian, 7 Feb. 1970, p. Io. 
withdrawal. African Americans may have been the 'most dovish' social group, but this did not translate into anti-war activism. ${ }^{166}$ Without pressure from below, the moderates could adopt an anti-war position without having to do very much about it.

Finally, the precipitous decline of the civil rights movement itself also prevented more black support for the peace movement. The late ig6os and early ig7os were a period of retrenchment, in which black groups sought to defend the gains already made. In such a context, involvement in anti-war activities was at best an unwelcome distraction. Indeed, those civil rights groups that did oppose the war in Vietnam vociferously, and adopted a radical critique of American society such as SNCC, CORE, the SCLC, and the Black Panthers - suffered catastrophic atrophy in the late ig6os and early ig7os. While the NAACP and Urban League also declined, they survived as mass-based national organizations, capable of wielding influence and a measure of power. Perhaps their caution in the mid-late I960s over issues such as Vietnam was justified.

The moderate black movement's response to Vietnam tells us much about the nature of the civil rights movement itself. When SNCG bitterly denounced the war in Vietnam in January I966 they were not merely subscribing to leftist dogma. When Roy Wilkins asked whether it was wrong for people to be patriotic and to support American troops fighting abroad he was not simply being an Uncle Tom. ${ }^{167}$ Both these responses were, in large part, shaped by civil rights movement experience. For groups like SNCC and CORE, I960-5 were years of disillusionment and radicalization. The refusal of the federal government to protect black workers from white violence, and the liberal betrayal at Atlantic City, undermined their faith in the American system - which they began to view as in need of fundamental change. This affected their response to the war - as one civil rights worker put it, 'our criticism of Vietnam ... does not come from what we know of Vietnam, but from what we know of America'. ${ }^{168}$ But for moderates like Roy Wilkins and Whitney Young, their experience during these years affirmed their faith in America. Their goal-the full participation of black Americans in all areas of national life - seemed to be achievable. The passage of landmark civil rights legislation in 1964 and 1965 , and the Great Society programmes, indicated that the United States was finally making real its founding promise of freedom and equality for all. There was thus nothing to gain, and a good deal to lose, by alienating liberals and the Johnson administration by opposing the war in Vietnam.

Many historians have viewed the war as a major contributor to the fracture and ultimate collapse of the civil rights movement in the late ig6os. Robert Cook,

\footnotetext{
166 Tom Wells, The war within: America's battle over Vietnam (Berkeley, Los Angeles, and London, I994), p. 70 .

167 SNCG statement on the Vietnam War, 6 Jan. I966, in Teodori, The new left, pp. 25 ${ }^{\mathrm{I}-2}$; and 'Wilkins raps King's civil rights policy', Worcester Sunday Telegram, I9 Apr. I967; NAACP papers, group IV box A86, folder 'Vietnam correspondence, I967-I968', Library of Congress.

168 Howard Zinn, unpublished article, winter I $_{95}$, in Howard Zinn papers, box 3 , folder 5 , SHSW.
} 
for example, has claimed that 'the intensification of US military intervention in Southeast Asia ... contributed further to the decline of the civil rights coalition'. ${ }^{169}$ With the unity provided by opposition to Jim Crow and black disfranchisement gone, and with difficult problems of economic inequality and political powerlessness remaining, the movement would likely have come under serious strain after I965 even without the added complication of Vietnam. While the war's role in the fragmentation of the civil rights movement has yet to be fully determined, the range of responses by black leaders and civil rights groups to Vietnam suggests that the war was important in highlighting existing divisions as well as in creating new ones.

169 Cook, Sweet land of liberty?, p. I76. Manfred Berg shares this assessment - see 'Guns, butter, and civil rights', pp. 2I $3^{-\mathrm{I}} 4$. 